\title{
Role of Ksharasutra suturing along with adjuvant therapy in the management of Parikartika (Chronic fissure-in-ano)
}

\author{
Research Article
}

\begin{abstract}
Dudhamal TS ${ }^{1^{*}}$, Baghel MS ${ }^{2}$, Bhuyan $C^{3}$, Gupta $K^{4}$
1. Assistant Professor, 3. Ex-Professor and HOD, 4. Associate Professor, Dept of Shalya Tantra, I.P.G.T. and R.A. Gujarat Ayurved University, Jamnagar 2. Director, I.P.G.T. and R.A. Gujarat Ayurved University, Jamnagar
\end{abstract}

\begin{abstract}
In Ayurvedic classics Parikartika has been depicted as complication of vamana, virechana, Atisara, etc. Parikartika can be correlated to fissure-in-ano in modern parlance a common disease among ano-rectal disorders. The main objective of this study was to evaluate the role of Ksharasutra suturing in chronic fissure-in-ano. In this study, total 50 patients of chronic fissure-in-ano aged between 18-60 years of either sex were selected for Ksharasutra suturing (KSS) which performed under spinal anesthesia. The Ksharasutra suturing was done once and after slough out of Ksharasutra wound was treated with Jatyadi taila and adjuvant drugs for four weeks. The study showed encouraging results with Ksharasutra Suturing in Parikartika without untoward effect.
\end{abstract}

Key Words: Fissure-in-ano, Parikartika, Ksharasutra.

\section{Introduction:}

Sushruta has described term "Parikartika" as a condition of Guda in which there is cutting and burning pain which is similar to that of fissure-in-ano. The factors responsible for causation of Parikartika are found as VamanaVirechana vyapada (complication of the vamana and virechena procedures), Basti vyapada (complication of the Basti procedures), Arsha, Atisara, Grahani, Udavarta, etc are mentioned in various texts. Parikartika (Chronic fissure-in-ano) is having the prevalence rate approximately $30 \%$ to $40 \%$ of anorectal sufferings where as the incidence is supposed to be very common in

*Corresponding Author:

Dudhamal TS

Assistant Professor, Department of Shalya Tantra, IPGT and RA, Gujarat Ayurved University Jamnagar, Gujarat

Email: drtsdudhamal@gmail.com constipated people particularly once who pass hard and dry stool with habit of suppressing stool urge. It is interesting to note that the maximum cases are of chronic fissure-in-ano which may be either due to late approach for treatment or failure of conservative treatments. So such cases require surgical intervention as a mandatory option to get complete relief.

The cause of fissure-in-ano is primarily constipation with passing of hard stool and secondary due to many diseases like chronic amoebic dysentery, diverticulitis, IBS, ulcerative colitis etc. and, even post hemorrhoidectomy or fistulectomy. The common site of fissurein-ano is 6 o'clock i.e. midline posterior, lower half of anal canal which is commonly found in young adults and after delivery in females. The disease has been classified into two viz. acute fissure-in-ano and chronic fissure-in-ano. In acute fissure-in-ano acute pain which is subsided by conservative management, however this relief is temporary and again patient has 
the symptoms of fissure after 2-3 months. In chronic cases, this may be accompanied by external and internal haemorrhoids, sentinel tag and pruritis ani. At present modern surgical treatments like Lord's anal dilatation, fissurectomy \& sphincterotomy for the anal fissure are available but they have their own limitations like recurrence, incontinence, etc.

In day to day practice Ksharasutra is receiving nationwide popularity with the extension to Western \& European countries. As per the information available, the developed countries like Japan have progressed to adopt this Ksharasutra therapy as an important therapeutic tool in their system. As it is a known fact that, satisfactory and curable result is being achieved in ano-rectal disorders like fistula and piles by application of Ksharasutra. Thus, keeping in view, the Parikartika (Chronic fissurein-ano), which is the most painful disease / condition of anal canal has been selected with following aim and objective.

\section{Aim \& objective:}

To evaluate the role of Ksharasutra suturing (KSS) in the management of Parikartika (Chronic fissure-in-ano).

\section{Material \& methods:}

\section{Selection of Patients:}

The patients of Parikartika (Chronic fissure-in-ano) were registered from OPD and IPD of the department of Shalya Tantra, irrespective of age, sex, occupation, and religion.

\section{Inclusion Criteria:}

- Diagnosed patients of Parikartika (Chronic fissure-in-ano) having sign and symptoms like fissure bed with or without sentinel tag, pain in ano, per rectal bleeding and history of constipation.

- Diagnosed patients of Parikartika associated with Arsha (piles) and Bhagandara (fistula-in-ano)
- Patients between the age group of 18 years to 60 Years.

\section{Exclusion Criteria:}

- Patients who were suffering from acute fissure-in-ano, carcinoma of ano-rectum, congenital anal stricture and congenital anal stenosis patients were excluded from this study.

- Patients who were positive for HIV, VDRL and Hepatitis-B were also excluded.

\section{Diagnostic Criteria:}

The diagnosis was made on the basis of clinical features and local inspection of anorectum, palpation i.e. PR digital examinations.

\section{Laboratory Investigations:}

Routine haemogram- $\mathrm{Hb} \%$, TLC, DLC, BT, CT, ESR, FBS, PPBS, RFT- Blood urea, Serum creatinine, Sr. Bilirubin, SGPT, SGOT HIV, VDRL, HBsAg. Urine Analysis and Stool examination were done for fitness of patients

Other Investigations:

Chest X-ray, Posterio-anterior view and ECG were carried out in patients of 40 years age to find out pulmonary and cardiac diseases for fitness.

\section{Materials:}

1) 50 diagnosed patients of Parikartika.

2) Standard Apamarga Ksharasutra.

3) Sphatikadi Yoga for sitz bath two times a day (Ref. Malasaya Roga Chikitsa Vignyan p.38)

4) Vatagajankush Vati -250 mg three times a day. (Ref. Bahishajya Ratnavali-26/116-118 p. 383)

5) Panchasakara Churna 5g at night (Ref. Sidhabhaishaja Manimala Chturtha guchha, Udavarta Chikitsa sloka 7 p.257)

6) Jatyadi taila for per anal installation (Ref. Bahishajya Ratnavali- 47 / 64-66 p. 597.) 


\section{Methodology:}

Ksharasutra Suturing (KSS) at

fissure bed followed by trans-fixation of sentinel tag was carried out under low spinal anesthesia which was divided into three step treatment procedure (trividha karma). (1)

\section{Operative procedure:}

a) Poorva karma (Pre-Operative Procedure):

1. Written informed consent was taken before intervention.

2. Patient was kept nil orally 6 hours before surgery.

3. Preparation of parts i.e. shaving of perineal area and spinal area.

4. Soap water enema at 8 am on the day of operation.

5. Inj. T. T., $0.5 \mathrm{ml}$, intramuscular (IM) was given before surgery.

6. Intra-dermal injection of xylocaine $2 \%$ was given for sensitivity test.

7. Low spinal anesthesia i.e. Sadal block was given to all the patients.

b) Pradhan Karma (Procedure of Ksharasutra Suturing (KSS):

1. The patient was laid down in the Lithotomy position after giving anesthesia.

2. Painting of perianal area with diluted Dettol solution in water and Betadine solution.

3. The peri-anal part was draped properly with sterilized cut sheet and plain linen sheets.

4. The whole fissure bed including all fibrous tissue was sutured by continuous suture with the help of round body curved needle of appropriate size, swaged with Ksharasutra, 2- 4 bites or as per the need / length of fissure bed.

5. Followed by trans-fixation of sentinel tag was done.

6. After proper haemostasis, ' $\mathrm{T}$ 'bandage was applied and patient was shifted to the ward
(MSW/FSW) in conscious and stable condition.

c) Paschhat Karma (Post-Operative Procedure):

1. The patient was laid down in head low position for 3 hours.

2. All patients were allowed to take liquids after 6 hours.

3. Appropriate anti-inflammatoryanalgesic and antibiotics were given for initial 3 days.

4. Avagaha Swedan (2) (Warm water sitz bath) with Sphatikadi Yoga was advised to take, two times a day.

5. Panchasakara churna $5 \mathrm{gm}$ at bed time with luke warm water was prescribed

6. Vatagajankusha vati $-250 \mathrm{mg}$ three times a day with plain water was prescribed

7. Post operative dressing was done with Jatyadi Tail, $10 \mathrm{ml}$ once a day as Matra Basti.

8. Patients were advised to take fiber rich diet and more liquids.

Duration of Treatment: Single stage operation for Parikartika with Ksharasutra suturing was done and patients were assessed on weekly interval up to 4 weeks in IPD (Male \& female Shalya ward) as well as after discharging from ward.

Follow-up period: One month after completion of the treatment to observe reoccurrence and any untoward effects of the treatment.

Statistical Test: For assessment of result by statistical analysis, paired' $t$ ' test was used.

Ethical Clearance:

IEC (Institutional Ethics Committee) letter No.PGT/Ethic2008/2009/2520; agenda no. 2, sr. no. 3, dated 24.11.2008. 


\section{Assessment criteria:}

Assessment was made by adopting gradation method on features of per-rectal pain, oozing of serous discharge from post Ksharasutra wound and healing of wound.

\section{Gradation for Pain:}

\section{Grade Description}

0 Patients free from pain

1 Pain at the time of defecation \& bearable which does not requires any analgesic drug

2 Pain at the time of defecation \& continuous which relieves after giving oral analgesic drug

3 Unbearable and continuous pain which relieves after giving injectable analgesic

\section{Gradation for Oozing:}

Grade Description

0 Observe dry gauze piece after 24 hours of dressing

1 Observe spot of blood on gauze piece after 24 hours of dressing

2 Observe partially wet gauze piece with blood after 24 hours of dressing

3 Observe complete wet gauze piece with blood after 24 hours of dressing

\section{Gradation for Wound Healing:}

\section{Grade Description}

0 Complete healed wound with healthy scar

1 Partially healed wound with healthy granulation tissue

2 Cleaned wound without slough / discharge

3 Fresh wound with discharge

\section{Overall assessment:}

Overall assessment of the results was done after completion of 4 weeks (28 Days) treatment as per the following criteria.

\section{Results}

\section{Criteria for Assessment}

\begin{tabular}{|l|l|}
\hline Cured & $\begin{array}{l}\text { Complete relief in pain } \\
\text { and bleeding during / after } \\
\text { defecation within 7 days } \\
\text { after cut through of suture } \\
\text { / removal of the } \\
\text { Ksharasutra }\end{array}$ \\
\hline Improvement & $\begin{array}{l}\text { Complete relief in pain } \\
\text { and bleeding during / after } \\
\text { defecation within 8-14 } \\
\text { days after cut through of } \\
\text { suture / removal of the } \\
\text { Ksharasutra }\end{array}$ \\
\hline Moderate & $\begin{array}{l}\text { Complete relief in pain } \\
\text { and bleeding during / after } \\
\text { defecation within 15-21 } \\
\text { days after cut through of } \\
\text { suture / removal of the } \\
\text { Ksharasutra }\end{array}$ \\
\hline $\begin{array}{l}\text { Mild } \\
\text { improvement }\end{array}$ & $\begin{array}{l}\text { Complete relief in pain } \\
\text { and bleeding during / after } \\
\text { defecation within 22-28 } \\
\text { days after cut through of } \\
\text { suture / removal of the } \\
\text { Ksharasutra }\end{array}$ \\
\hline Un-Changed & $\begin{array}{l}\text { No relief in pain and } \\
\text { bleeding during / after } \\
\text { defecation even after 28 } \\
\text { days (04 weeks) after cut } \\
\text { through of suture / } \\
\text { removal of } \\
\text { Ksharasutra }\end{array}$ \\
\hline
\end{tabular}

Observations \& results:

Table -1; General Observations: $\boldsymbol{n}=\mathbf{5 0}$

\begin{tabular}{|l|c|c|}
\hline Observations & $\begin{array}{c}\text { No. of } \\
\text { Patients } \\
\text { (maximu } \\
\text { m) }\end{array}$ & $\begin{array}{c}\text { Percentage } \\
\text { (Maximu } \\
\text { m) }\end{array}$ \\
\hline $\begin{array}{l}\text { Age (31-45 } \\
\text { years) }\end{array}$ & 22 & $44 \%$ \\
\hline Sex (Male) & 33 & $66 \%$ \\
\hline $\begin{array}{l}\text { Occupation } \\
\text { (Laborer) }\end{array}$ & 19 & $38 \%$ \\
\hline Religion & 46 & $96 \%$ \\
\hline
\end{tabular}




\begin{tabular}{|l|c|c|}
\hline (Hindu) & (2) & $68 \%$ \\
\hline $\begin{array}{l}\text { Dwelling } \\
\text { Status (Urban) }\end{array}$ & 32 & $64 \%$ \\
\hline $\begin{array}{l}\text { Socio } \\
\text { economic } \\
\text { status (Poor) }\end{array}$ & 40 & $80 \%$ \\
\hline $\begin{array}{l}\text { Sleep pattern } \\
\text { (Sound sleep) }\end{array}$ & 18 & $36 \%$ \\
\hline $\begin{array}{l}\text { Diet habit } \\
\text { (Vishamashan } \\
\text { a) }\end{array}$ & 33 & $66 \%$ \\
\hline $\begin{array}{l}\text { Koshta } \\
\text { (Madhyam) }\end{array}$ & 22 & $70 \%$ \\
\hline $\begin{array}{l}\text { Agni } \\
\text { (Mandagni) }\end{array}$ & $44 \%$ \\
\hline $\begin{array}{l}\text { Bowel habits } \\
\text { (Irregular) }\end{array}$ & 35 \\
\hline $\begin{array}{l}\text { Chronicity } \\
\text { (6month - } \\
\text { 1year ) }\end{array}$ & & $36 \%$ \\
\hline
\end{tabular}

Table-4; Status of anal sphincters tone: $\boldsymbol{n}=\mathbf{5 0}$

\begin{tabular}{|l|c|c|}
\hline $\begin{array}{l}\text { Anal Sphincter } \\
\text { Tone }\end{array}$ & $\begin{array}{c}\text { No. of } \\
\text { Patients }\end{array}$ & $\begin{array}{c}\text { Percent } \\
\text { age }\end{array}$ \\
\hline Spasmodic & 37 & $74 \%$ \\
\hline Normal & 11 & $22 \%$ \\
\hline Relax & 2 & $4 \%$ \\
\hline
\end{tabular}

Table-5; Symptoms of Parikartika: $\boldsymbol{n}=\mathbf{5 0}$

\begin{tabular}{|l|c|c|}
\hline Symptoms & $\begin{array}{c}\text { No. of } \\
\text { Patients }\end{array}$ & Percentage \\
\hline Vedana (Pain) & 50 & $100 \%$ \\
\hline $\begin{array}{l}\text { Malabadhata } \\
\text { (Constipation) }\end{array}$ & 46 & $92 \%$ \\
\hline $\begin{array}{l}\text { Raktasrava ( } \\
\text { Bleeding) }\end{array}$ & 36 & $72 \%$ \\
\hline
\end{tabular}

Table-6; Associated Diseases: $\boldsymbol{n}=\mathbf{5 0}$

\begin{tabular}{|l|c|c|}
\hline Associated Diseases & $\begin{array}{c}\text { No. of } \\
\text { Patients }\end{array}$ & $\begin{array}{c}\text { Percen } \\
\text { tage }\end{array}$ \\
\hline $\begin{array}{l}\text { Bahya Arsha } \\
\text { (External Piles) }\end{array}$ & 12 & $24 \%$ \\
\hline $\begin{array}{l}\text { Abhyantar Arsha } \\
\text { (Internal Piles) }\end{array}$ & 12 & $24 \%$ \\
\hline $\begin{array}{l}\text { Bhagandara } \\
\text { (Fistula-in-ano) }\end{array}$ & 2 & $4 \%$ \\
\hline Total & 26 & $52 \%$ \\
\hline
\end{tabular}

Table-2; Position of fissure-in-ano: $n=50$

\begin{tabular}{|l|c|c|c|c|}
\hline $\begin{array}{l}\text { Position of } \\
\text { fissure }\end{array}$ & $\begin{array}{c}\text { No. of } \\
\text { Patient } \\
\text { s }\end{array}$ & $\begin{array}{c}\text { Perc } \\
\text { entag } \\
\text { e }\end{array}$ & $\begin{array}{c}\text { M } \\
\text { al } \\
\text { e }\end{array}$ & $\begin{array}{c}\text { Fe } \\
\text { ma } \\
\text { le }\end{array}$ \\
\hline $\begin{array}{l}\text { Posterior (6 } \\
\text { o'clock) }\end{array}$ & 31 & $62 \%$ & 31 & 00 \\
\hline $\begin{array}{l}\text { Anterior (12 } \\
\text { o'clock) }\end{array}$ & 7 & $14 \%$ & 00 & 07 \\
\hline $\begin{array}{l}\text { Ant. \& Post. } \\
\text { (6\&12 } \\
\text { o'clock) }\end{array}$ & 12 & $24 \%$ & 00 & 12 \\
\hline $\begin{array}{l}\text { Other (7 } \\
\text { o'clock) }\end{array}$ & 00 & 00 & 01 & 00 \\
\hline
\end{tabular}

Table-3; Presence of Sentinel tag: $\boldsymbol{n}=\mathbf{5 0}$

\begin{tabular}{|l|c|c|}
\hline $\begin{array}{l}\text { Presence of } \\
\text { Sentinel tag }\end{array}$ & $\begin{array}{c}\text { No. of } \\
\text { Patients }\end{array}$ & $\begin{array}{c}\text { Percen } \\
\text { tage }\end{array}$ \\
\hline 6 o'clock & 26 & $52 \%$ \\
\hline 12 o'clock & 7 & $14 \%$ \\
\hline 6,12 o'clock & 6 & $12 \%$ \\
\hline $\begin{array}{l}\text { Other position (7 or } \\
\text { 11 o'clock) }\end{array}$ & 4 & $8 \%$ \\
\hline Absent & 7 & $12 \%$ \\
\hline
\end{tabular}

Table-7; Spontaneous slough out of Ksharasutra: $n=\mathbf{5 0}$

\begin{tabular}{|l|c|c|}
\hline $\begin{array}{l}\text { Slough out of } \\
\text { KS }\end{array}$ & $\begin{array}{c}\text { No. of } \\
\text { Patients }\end{array}$ & $\begin{array}{c}\text { Percent } \\
\text { age }\end{array}$ \\
\hline $\begin{array}{l}3^{\text {rd }} \text { post } \\
\text { operative day }\end{array}$ & 6 & $12 \%$ \\
\hline $\begin{array}{l}4^{\text {th }} \text { post operative } \\
\text { day }\end{array}$ & 21 & $42 \%$ \\
\hline $\begin{array}{l}5^{\text {th }} \text { post operative } \\
\text { day }\end{array}$ & 21 & $42 \%$ \\
\hline $\begin{array}{l}6^{\text {th }} \text { post operative } \\
\text { day }\end{array}$ & 2 & $6 \%$ \\
\hline
\end{tabular}

Table-8; Pain Relief after KSS: $\boldsymbol{n}=\mathbf{5 0}$

\begin{tabular}{|c|c|c|c|c|c|c|}
\hline $\begin{array}{l}\text { Da } \\
\text { ys }\end{array}$ & $\begin{array}{l}\text { Me } \\
\text { an }\end{array}$ & $\begin{array}{l}\text { SE } \\
\mathbf{M}\end{array}$ & $\begin{array}{l}\text { St } \\
\text { d } \\
\text { de } \\
\text { v }\end{array}$ & $\begin{array}{l}\text { M } \\
\text { Diff }\end{array}$ & $\mathbf{T}$ & p \\
\hline $1^{\text {st }}$ & 2.1 & \pm & 0.6 & - & 8.0 & $<0.0$ \\
\hline
\end{tabular}




\begin{tabular}{|c|c|c|c|c|c|c|}
\hline $\begin{array}{l}\mathrm{Da} \\
\mathrm{y}\end{array}$ & 20 & $\begin{array}{l}0.08 \\
87\end{array}$ & 27 & & 88 & $01^{*}$ \\
\hline $\begin{array}{l}7^{\text {th }} \\
\mathrm{Da} \\
\mathrm{y}\end{array}$ & $\begin{array}{r}1.0 \\
40\end{array}$ & $\begin{array}{l} \pm \\
0.13 \\
1\end{array}$ & $\begin{array}{l}0.9 \\
25\end{array}$ & $\begin{array}{l}\downarrow 1 . \\
080\end{array}$ & & \\
\hline $14^{t}$ & 0.2 & \pm 0.0 & 0.5 & $\downarrow 1$. & 16. & $<0.0$ \\
\hline $\begin{array}{l}\mathrm{Da} \\
\mathrm{y}\end{array}$ & 60 & 746 & 27 & 860 & 803 & $01 *$ \\
\hline $\begin{array}{l}21^{\mathrm{S}} \\
\mathrm{t}\end{array}$ & 0.0 & \pm 0.0 & 0.1 & $\downarrow 2$. & 21. & $<0.0$ \\
\hline $\begin{array}{l}\text { da } \\
y\end{array}$ & 400 & 280 & 98 & 080 & 157 & $01 *$ \\
\hline $\begin{array}{l}28^{\mathrm{t}} \\
\mathrm{h}\end{array}$ & 0.0 & \pm 0.0 & 0.0 & $\downarrow 2$. & 23. & $<0.0$ \\
\hline $\begin{array}{l}\mathrm{da} \\
\mathrm{y}\end{array}$ & 00 & 00 & 00 & 120 & 898 & $01 *$ \\
\hline
\end{tabular}

Table -9; Relief in Oozing after KSS: $\boldsymbol{n}=\mathbf{5 0}$

\begin{tabular}{|c|c|c|c|c|c|c|}
\hline $\begin{array}{l}\text { Da } \\
\text { ys }\end{array}$ & $\begin{array}{r}\text { Me } \\
\text { an }\end{array}$ & $\begin{array}{l}\text { SE } \\
\mathbf{M}\end{array}$ & $\begin{array}{l}\text { St } \\
\text { d } \\
\text { de } \\
\text { v }\end{array}$ & $\begin{array}{l}\text { M } \\
\text { Diff }\end{array}$ & $\mathbf{T}$ & $\mathbf{p}$ \\
\hline $\begin{array}{l}1^{\text {st }} \\
\mathrm{Da} \\
y\end{array}$ & $\begin{array}{r}2.5 \\
00\end{array}$ & $\begin{array}{l} \pm 0.0 \\
769\end{array}$ & $\begin{array}{l}0.5 \\
44\end{array}$ & - & 11. & $<0.0$ \\
\hline $\begin{array}{l}7^{\text {th }} \\
\mathrm{Da} \\
y\end{array}$ & $\begin{array}{r}0.9 \\
20\end{array}$ & $\begin{array}{l} \pm 0.1 \\
66\end{array}$ & $\begin{array}{l}1.1 \\
75\end{array}$ & $\begin{array}{l}\downarrow 1 . \\
580\end{array}$ & 766 & $01^{*}$ \\
\hline $\begin{array}{l}14^{\mathrm{t}} \\
\mathrm{h} \\
\mathrm{Da} \\
\mathrm{y}\end{array}$ & $\begin{array}{r}0.1 \\
000\end{array}$ & $\begin{array}{l} \pm 0.0 \\
589\end{array}$ & $\begin{array}{l}0.4 \\
16\end{array}$ & $\begin{array}{l}\downarrow 2 . \\
400\end{array}$ & $\begin{array}{c}28 . \\
000\end{array}$ & $\begin{array}{l}<0.0 \\
01 *\end{array}$ \\
\hline $\begin{array}{l}21^{\mathrm{s}} \\
\mathrm{t} \\
\mathrm{da} \\
\mathrm{y}\end{array}$ & $\begin{array}{r}0.0 \\
00\end{array}$ & $\begin{array}{l} \pm 0.0 \\
00\end{array}$ & $\begin{array}{l}0.0 \\
00\end{array}$ & $\begin{array}{l}\downarrow 2 . \\
500\end{array}$ & $\begin{array}{l}32 . \\
497\end{array}$ & $\begin{array}{l}<0.0 \\
01 *\end{array}$ \\
\hline $\begin{array}{l}28^{t} \\
h \\
d a \\
y\end{array}$ & $\begin{array}{r}0.0 \\
00\end{array}$ & $\begin{array}{l} \pm 0.0 \\
00\end{array}$ & $\begin{array}{l}0.0 \\
00\end{array}$ & $\begin{array}{l}\downarrow 2 . \\
500\end{array}$ & $\begin{array}{l}32 . \\
497\end{array}$ & $\begin{array}{l}<0.0 \\
01 *\end{array}$ \\
\hline
\end{tabular}

Table-10; Status of Wound Healing after KSS: $n=\mathbf{5 0}$

\begin{tabular}{|c|c|c|c|c|c|c|}
\hline $\begin{array}{l}\text { Da } \\
\text { ys }\end{array}$ & $\begin{array}{c}\text { Me } \\
\text { an }\end{array}$ & $\begin{array}{l}\text { SE } \\
\mathbf{M}\end{array}$ & $\begin{array}{l}\text { St } \\
\text { d } \\
\text { de } \\
\text { v }\end{array}$ & $\begin{array}{l}\text { M } \\
\text { Diff }\end{array}$ & $\mathbf{T}$ & $\mathbf{p}$ \\
\hline $\begin{array}{l}1^{\text {st }} \\
\mathrm{Da} \\
\mathrm{y}\end{array}$ & $\begin{array}{r}4.0 \\
00\end{array}$ & $\begin{array}{l} \pm 0.0 \\
00\end{array}$ & $\begin{array}{l}0.0 \\
00\end{array}$ & - & \multirow{2}{*}{$\begin{array}{c}14 . \\
830\end{array}$} & \multirow{2}{*}{$\begin{array}{l}<0.0 \\
01^{*}\end{array}$} \\
\hline $\begin{array}{l}7^{\text {th }} \\
\mathrm{Da} \\
\mathrm{y}\end{array}$ & $\begin{array}{r}2.7 \\
80\end{array}$ & $\begin{array}{l} \pm 0.0 \\
823\end{array}$ & $\begin{array}{l}0.5 \\
82\end{array}$ & $\begin{array}{l}\downarrow 1 . \\
220\end{array}$ & & \\
\hline $\begin{array}{l}14^{\mathrm{t}} \\
\mathrm{h} \\
\mathrm{Da} \\
\mathrm{y}\end{array}$ & $\begin{array}{r}2.2 \\
80\end{array}$ & $\begin{array}{l} \pm 0.0 \\
641\end{array}$ & $\begin{array}{l}0.4 \\
54\end{array}$ & $\begin{array}{l}\downarrow 1 . \\
720\end{array}$ & $\begin{array}{l}26 . \\
815\end{array}$ & $\begin{array}{l}<0.0 \\
01^{*}\end{array}$ \\
\hline $\begin{array}{l}21^{\mathrm{s}} \\
\mathrm{d} \\
\mathrm{da} \\
\mathrm{y}\end{array}$ & $\begin{array}{r}1.2 \\
40\end{array}$ & $\begin{array}{l} \pm 0.1 \\
39\end{array}$ & $\begin{array}{l}0.9 \\
81\end{array}$ & $\begin{array}{l}\downarrow 2 . \\
760\end{array}$ & $\begin{array}{l}19 . \\
902\end{array}$ & $\begin{array}{l}<0.0 \\
01^{*}\end{array}$ \\
\hline $\begin{array}{l}28^{\mathrm{t}} \\
\mathrm{h} \\
\mathrm{da} \\
\mathrm{y}\end{array}$ & $\begin{array}{r}0.1 \\
60\end{array}$ & $\begin{array}{l} \pm 0.0 \\
775\end{array}$ & $\begin{array}{l}0.5 \\
48\end{array}$ & $\begin{array}{l}\downarrow 3 . \\
840\end{array}$ & $\begin{array}{l}49 . \\
540\end{array}$ & $\begin{array}{l}<0.0 \\
01^{*}\end{array}$ \\
\hline
\end{tabular}

* Highly significant results.

Table-11; Overall Result: $\boldsymbol{n}=\mathbf{5 0}$

\begin{tabular}{|l|c|c|}
\hline $\begin{array}{l}\text { Overall result of } \\
\text { KSS }\end{array}$ & $\begin{array}{c}\text { No. of } \\
\text { Patients }\end{array}$ & $\begin{array}{c}\text { Percent } \\
\text { age }\end{array}$ \\
\hline Cured & 28 & $56 \%$ \\
\hline Improvement & 14 & $28 \%$ \\
\hline $\begin{array}{l}\text { Moderate } \\
\text { improvement }\end{array}$ & 5 & $10 \%$ \\
\hline $\begin{array}{l}\text { Mild } \\
\text { improvement }\end{array}$ & 3 & $6 \%$ \\
\hline No relief & 0 & 0 \\
\hline
\end{tabular}

\section{Discussion:}

\section{Discussion on Observations:}

Maximum number of observed finding of demographic data is shown in (table-1). Maximum numbers of patients $(44 \%)$ were observed in age group between 31-45 years because young middle aged patients were most of the sufferers due to more family responsibility. Junk and spicy food consumption becomes routine diet to spare 
more time for fulfilling their responsibility. In this study, $66 \%$ patients were males might be due to more awareness in comparison to females but fissure-in-ano can occur irrespective of gender.

Laborer patients were observed maximum (38\%) might be the flows of patients in Govt. hospitals are more of laborer than other classes. Patients belong to Hindu religion were maximum $(96 \%)$ indicates dominance of Hindu population in study place but as per available textual references, there is no such relation was found. The patients from urban back ground were noted maximum (68\%) might be due to sedentary life style prevailing in such society. Other factors like more consumption of spicy and junk foods which are held responsible for Agnimandya and chronic constipation; ultimately lead to Parikartika. Another important reason might be sought as study carried out in urban area but only on these findings it is difficult to say that the incidences of Parikartika are more in urban area. The observation shows that socio-economically poor patients were observed more (64\%), might be due to negligence about the gravity of Parikartika in acute condition which leads to chronic stage after repeated attacks. Sound sleep was found in $80 \%$ of patients which showed that Parikartika did not disturb sleep. The pain in ano is mostly occurred after defecation and may likely to be present for minutes to hours; after that patients feel comfortable. (3)

In this study, Vishamashana type of dietetic habit was seen in $36 \%$ patients due to such habit patients were suffering from indigestion-agnimandya-malabdhata and ultimately Parikartika. Patients having Madhyam koshtha were $36 \%$ which shows predominance of vata dosha; considered as a prime dosha vitiated in pain dominating disorder like Parikartika. In Ayurveda, mandagni is said to be root cause of all diseases, (4) particularly disorders related to GIT and anorectal region. In mandagni cases, improper digestion of food takes place which may leads to either constipation or diarrhea and ultimately Parikartika. Such observations were verified in this study as $66 \%$ patients were having features of mandagni and constipation. The $70 \%$ of patients had irregular bowel habit which might be due to agnimandya and improper digestion of foods, leads to vitiation of vata dosha particularly apan vayu and causes irregularity in evacuation of stool. Hence, sometime patients suffered from constipation and passed hard stool which leads to Parikartika. In this study, maximum patients (44\%) were having chronicity from 6 months to one year. $28 \%$ patients having chronicity more than one year to 2 year while remaining patients had chronicity of symptoms morethan 2 years.

All patients were selected of chronic fissure-in-ano because aim of study was fixed to study effect of Ksharasutra in chronic fissure-in-ano. The $62 \%$ patients were observed with fissure at posterior (6 o'clock) position of anus (Table-2) might be due direct pressure of stool at posterior aspect of anal canal during defecation. (5) 14\% females had revealed fissure at 12 o'clock position due to trauma to anterior aspect of the anal canal during delivering baby. The sentinel tag is mostly found in cases of chronic fissure-in-ano which develops to guard the fissure from more tear of anal verge so in maximum $88 \%$ of patients had developed sentinel tag (Table-3). (6) In the study, on per rectal digital examination $74 \%$ patients were noted for spasmodic anal sphincter (Table-4). In chronic fissure-in-ano sphincters became spasmodic due to increased intra-rectal pressure and causes delay in healing of fissure bed. Such findings were observed in the study and also supported by previous research work. (7) In entire $(100 \%)$ patients pain was observed as it is the cardinal symptom of 
Parikartika. Other symptoms i.e constipation was observed in $92 \%$ of patients because it is the main causative factor of Parikartika and other ano-rectal disorder. Raktasrava (Per rectal bleeding) was seen in $72 \%$ patients because it was due to tear of fissure wound and sometime it was in little amount so patients cannot notice (Table-5). In this study associate disease like external and internal pile were observed in $24 \%$ of patients while in $4 \%$ patients had Fistula-in-ano with fissure (Table-6) which was treated accordingly with Ksharasutra.

In $42 \%$ of patients, Ksharasutra sutured at fissure bed, sloughed out spontaneously on $4^{\text {th }}$ and $5^{\text {th }}$ post operative day in maximum patients. Very few patients i.e. only $6 \%$ patients had taken 6 days to slough out Ksharasutra from fissure bed. Hence, it is proven that sloughing out of sutured Ksharasutra is absolutely a mechanical phenomenon (Table-7).

\section{Discussion on Results:}

The results were assessed to find out efficacy of Ksharasutra suturing by relief in post operative pain, oozing and days required for complete wound healing. This assessment has been done by weekly interval i.e. on $7^{\text {th }}$ day, $14^{\text {th }}$ day, $21^{\text {st }}$ day and on $28^{\text {th }}$ post operative day. In all patients pain relief was achieved by $28^{\text {th }}$ post operative day (Table- 8) and statistically highly significant $(\mathrm{p}<0.001)$ results had been seen in weekly interval. The main symptom of Parikartika is Vedana (pain in ano). In cases of Parikartika, sphincter spasm and presence of fissure lead to painful defecation and because of that patient scared and avoid to defecating stool. This situation further leads to constipation again and again as avoiding passing stool is again responsible for constipation. So, after surgery, pain wear off due to relaxation of anal sphincters as well as removal of unhealthy tissue by KSS from fissure bed which promotes healthy and complete healing.

Slight oozing from clean wound of fissure bed was present after Ksharasutra removal in the form of serous discharge. Maximum patients have relief in oozing within $7^{\text {th }}$ post operative day and very few patients had taken 14 days to stop oozing with highly significant results on weekly assessment (Table-9). Smeared Kshara on Ksharasutra is alkaline in nature $(\mathrm{pH}-$ 10.39) which is capable to inhibit the bacterial growth. So, created wound after cut through of Ksharasutra was found in Shudhda avashtha (Clean and noninfected wound). Discharge of serous is due to the inflammation present around the wound in early days but use of Jatyadi tail as Matra Basti $10 \mathrm{ml}$ per rectum once daily was found helpful to control oozing.

The spontaneous cut through of Ksharasutra leads to fresh wound so maximum patients showed wound healing after 21 days. Sitz bath with Sphatikadi yoga and Matra basti of Jatyadi taila definitely helped to achieve the conditions of Shodhan and Ropan of wound. In case of wound healing statistically significant results were seen in weekly interval (Table-10) but wound healing was not observed up to 28 days in all patients. Because in this study 4 patients had taken more than 28 days for complete wound healing due to 1 patients had associate disease fistula-in-ano and 2 patients had develop subcutaneous fistula-in-ano and one abscess as post operative complication after Ksharasutra suturing.

Malbaddhata (constipation) was relieved in all patients within 14 days by combined use of Panchasakara Churna orally and Matra Basti of Jatyadi Taila locally. Panchasakar Churna acted as anulomaka (laxative) to evacuate feces easy and smoothly. Jatyadi Taila is found helpful in relieving the Rukshata, Malbaddhata and anal sphincter spasm by virtue of its Snigdha, Shodhan and soothing properties. Raktasrava was 
stopped after Ksharasutra suturing in all patients within 7 days; as fissure bed was removed and form a clean and healthy wound which may have slight oozing. The oozing in the form of serous discharge was considered as parameter to assess the result of KSS. Hence, it can be inferred that Ksharasutra suturing was effective to stop the bleeding as fissure bed was removed and no further trauma occurred to the healthy wound.

Every surgical procedure including has its own merits and demerits. In this study only 3 patients had complications (1abscess 2-subcutaneous fistula) during treatment period of one month. It might be due to excessive local tissue reaction of Kshara or improper hygiene. These patients were treated accordingly by incision and drainage (I \& D) of abscess while fistula cases were treated with Ksharasutra application. As these were minor complications and patients were cured completely but they required more time for complete wound healing and shown moderate/mild improvement.

\section{Overall Result:}

Total 56\% patients were cured while $28 \%$ patients were observed under improvement category. $10 \%$ patients were having moderate improvement while $6 \%$ patients were had mild improvement. Hence, all patients had got relief as per assessment criteria fixed for required period for relief in sign and symptoms and none of patient was found under "No relief" category (Table-11).

\section{Probable mode of action:}

The Apamarga Kshara having properties of Chhedana (Excision), Bhedana (Incision), Ksharana (Debridation), Stambhana (Haemostatic), Shodhana (Purification/Sterilization) and Ropana (Healing). Chhedana and Bhedana properties of Kshara are helpful to excise sentinel tag as well as fissure bed. (8) Ksharasutra sutured at fissure bed excises the fibrotic tissue by action of Ksharana and removes unhealthy fibrous tissue and debris; making the wound Shuddha / healthy by Shodhana property. (9) The Snuhi Ksheer is slightly acidic in nature and also has antibacterial property (10) which helped to check secondary infection. The Haridra has antiinflammatory as well as anti-bacterial (11) properties and hence it is capable to make the wound clean, healthy and promote early healing. (12)

The Sphatikadi Yoga (13) was used for Avagaha Swedana (sitz bath); (14) has Shodhana, Stambhana, Shothahara (antiinflammatory) and Vedanahara (Analgesic) properties, which helped to relieve pain, local Shotha (edema) as well as to stop oozing and maintained perianl hygiene. Panchasakara churna is specially indicated for Vibandha (constipation); (15) in which Senna (Cassia angustifolia), Haritaki (Terminalia chebula) and Shatapushpa (Fenicum vulgare) have the Anulomana (Laxative) property and rendered an action of easy and smooth evacuation of stool. The ingredients of Vatagajankusha Vati are Vatahara, Shothahara, Shulahara, and Tridoshaghna so prescribed to pacify the Vata Dosha. This formulation contains Vatsanabha (Aconitum ferox) as one of the important ingredient which plays role as Vedanahara (analgesic) by acting through the nervous system (16) might be due to Vyavayi and Vikasi properties of drug. Most of ingredients used in Jatyadi Taila are Shothahara, Vedanasthapana and Ropaka which are important requirements of healing wound. The ingredients of the Taila like Neem (Azadirachta indica) (17) and Daruharidra (Beriberi aristate DC) are proven drugs to check bacterial growth and promotes wound healing.

\section{Conclusion:}

Finally it was concluded from the study that Ksharasutra suturing is effective procedure in Parikartika along 
with adjuvant drugs without any adverse effect.

\section{References:}

1. Ambikadatta Shastri, Sushruta's Sushruta Samhita, Sutra Sthana 5/3; $12^{\text {th }}$ ed. Chowkhambha Sanskrit Sanshtan, Varanasi. 2001. p. 15.

2. Ambikadatta Shastri, Sushruta's Sushruta Samhita, Chikitsa Sthana $8 / 36 ; 12^{\text {th }}$ ed. Chowkhambha Sanskrit Sanshtan, Varanasi. 2001. p. 45.

3. Das S. A Concise Textbook of surgery. Chronic fissure-in-ano. $6^{\text {th }}$ ed. Kolkata: Dr. S.

Das publication.2010. p. 967.

4. Kashinath Shastri, Astanga Hridayam, Nidan sthana, $12 / 1 ; 1^{\text {st }}$ ed. Krishnadas Academy, Varanasi. 1994. p.133.

5. Goligher J. Surgery of the Anus Rectum and colon. Fissure in ano. $5^{\text {th }}$ ed. A.I.T.B.S. Publishers and distributors, Delhi. 2002. p. 158.

6. Baily and love's Short Practice of surgery. Chronic fissure in ano. $25^{\text {th }}$ ed. UK Hodder Arnold part of Hachette. 2008. p.1252

7. Jonas M, Scholefield JH. Anal Fissure. Gastroenterol Clin North Am. 2001; 30: $167-81$

8. Ambikadatta Shastri, Sushruta's Sushruta Samhita, Sutra Sthana11/3; $12^{\text {th }}$ ed. Chowkhambha Sanskrit Sanshtan, Varanasi. 2001. p. 34.

9. Ambikadatta Shastri, Sushruta's Sushruta Samhita, Sutra Sthana11/5; $12^{\text {th }}$ ed. Chowkhambha Sanskrit Sanshtan, Varanasi. 2001.p. 34.

10. Rasik AM, Shukla A, Patnaik GK, Dhawan BN, Kulshrestha DK,
Srivastava S. Wound healing activity of latex of Euphorbia neriifolia Linn. Indian Journ of Pharmacology. 1996; 28 (2); p.107-109.

11. Negi PS, Jayaprakasha GK, Rao ML, \& Sakariah KK. Antibacterial activity of turmeric oil: a byproduct from curcumin manufacture. Journal of Agricultural and Food Chemistry 1999; 47(10)4297-300.

12. Synopsis of turmeric's healing properties. (n.d.). Retrieved fromhttp://www.turmeric.co.in/turmeri c_ayurvedic_use.htm.Assessed on 12.01 .2012$.

13. Bhuyan C. Malasaya Roga Chikitsa Vignyan (Anubhuta yoga). 1st ed. Indian Proctology Society, Puri-2. 1998. p.38.

14. Jensen SL. Treatment of first episode of acute anal fissure - a prospective randomized study of lignocaine ointment vs. hydrocortisone ointment vs. warm Sitz bath plus bran. BMJ 1986; 292 (6529):1167-69.

15. Bhatta K. Sidhabhaishaja Manimala, Udavarta Chikitsa, 4/7, 2nd ed.: Krishnadas Acadomy, Varanasi.1999. p.257.

16. Panda AK and Debnath SK. Overdose effect of aconite containing Ayurvedic Medicine ('Mahashankha Vati'). Int J Ayurveda Res. 2010 Jul-Sep; 1(3):18386.

17. Biswas, Kausik ; Chattopadhyay, Ishita; Banerjee, Ranajit K; Bandyopadhyay, Uday. (2002); Biological activities and medicinal properties of neem (Azadirachta indica) Current science 2002; 82 (11):1336-45 